\title{
19. YÜZYILIN SIRADIŞI SANAT HAREKETİ: PRE-RAPHAELITE KARDEŞLİĞİ VE SEMBOLIZZMI*
}

Meltem YAŞDAĞ**

Özet

İngiltere'de 1848 y1lında Kraliyet Akademisi öğrencisi üç genç; William Holman Hunt, John Everett Millais ve Dante Gabriel Rossetti, akademinin idealist eğitim sistemine karşı gelerek Pre-Raphaelite Brotherhood (Pre-Raphaelite Kardeşliği) adında bir grup kurmuşlardır. Pre-Raphaelite Kardeşliği, etkin bir şekilde 1848-1854 yılları arasında faaliyet göstermiştir. Kardeşlik, akademinin geleneksel kurallarına başkaldırı olarak sanatın bir tür ahlaki amaca hizmet etmesi gerektiğini savunmuştur. İngiliz resim tarihinde eserleri için seçtikleri konular ve bu konuları izleyiciye aktarma konusunda kullandıkları semboller nedeniyle 19. yüzyılın sanat dünyasına yeni bir soluk getiren Pre-Raphaelite Kardeşliği, resimlerindeki sembolizm ve bu sembolizmin kaynakları ile ön plana çıkmıştır. Bu nedenle çalışmada, İngiltere'de 19. yüzyılda politik ve sosyal yaşamın sanatta yorumlanmasında katkısı olduğu düşünülen Pre-Raphaelite Kardeşliği'nin, eserlerindeki tasvirleri sembol olarak kullanırken neyi, nasıl anlattıkları ve hedefleri irdelenmiştir.

Anahtar Kelimeler: Resim Sanatı, Sembolizm, Ingiliz Resim Sanatı, Viktorya Dönemi, Endüstri Devrimi.

\section{2on \\ EXTRAORDINARY ART MOVEMENT OF $19^{\text {th }}$ CENTURY: PRE-RAPHAELITE BROTHERHOOD AND THEIR SYMBOLISM}

\begin{abstract}
$\underline{\text { Abstract }}$
In England, in 1848, three young Royal Academy students; William Holman Hunt, John Everett Millais and Dante Gabriel Rossetti, founded a group called Pre-Raphaelite Brotherhood, acting against academy's idealistic system. Pre-Raphaelite Brotherhood was effectively operated between 1848-1854. Pre-Raphaelites as an unsurprising movement against the traditional rules of academic art argued that art should serve to moral purpose. In the history of British Painting, by the accomplishment of the subjects chosen for their works and to transfer these issues to viewer by means of symbols that brought a new breath into the world of $19^{\text {th }}$ century art world, came to the forefront by symbolism in their paintings and the sources of their symbolism. For this reason, study explores what they are describing, how they describe it and their goals while using the depictions in their works as a symbol in the paintings of Pre-Raphaelite Brotherhood, which was thought to have contributed to the interpretation of political and social life in art in $19^{\text {th }}$ century.
\end{abstract}

Keywords: Painting Art, Symbolism, British Painting Art, Victorian Era, Industrial Revolution

\footnotetext{
* Bu çalışma, Prof. Dr. Kıymet GİRAY danışmanlığında tamamlanmış olan doktora tezinden üretilmiştir.

** Dr., Kültür ve Turizm Uzmanı. Kültür ve Turizm Bakanlığı, Kültür Varlıkları ve Müzeler Genel Müdürlügü̈, e-mail: meltem.yasdag@kultur.gov.tr
} 
Viktorya Dönemi (1837-1901), İngiliz tarihinde köklü değişim ve dönüşümlerin yaşandığı bir dönem olmuştur. Bu dönem boyunca, dünyanın en büyük imparatorluğunu yöneten İngiltere, Sanayi Devrimi'nin etkisi altında büyük buluşları ve ekonomik açıdan başarıyı vaad ederken, hızlı sanayileşmenin sonucu olarak toplumu; köyden kente göç, kalabalık şehirler, genç ölümler, işsizlik ve yeni sınıfların ortaya çıkışı gibi sorunlar ile karşı karşıya bırakmıştır. ${ }^{1}$ Aslında İngiltere'nin ekonomi alanında Endüstri Devrimi'nin sağladığı avantajlar ile yakaladığı egemenlik, siyasi ve iktisadi bakımdan olumlu ve olumsuz yeni gelişmelere neden olurken; bu gelişmeler 19. yüzyılın ilk yarısında tahta çıkan Kraliçe Viktorya'nın etkisiyle kültürel açıdan da yeni bir dönemin başlamasına neden olmuştur. Viktorya Dönemi'nde meydana gelen sosyal, ekonomik ve kültürel değişikliklerin toplum üzerinde yarattığ 1 etkiler ve bu etkilerin İngiliz resim sanatına yansıması ise 18. yüzyıl sonunda yine Kraliyet ailesi tarafindan kurulan Kraliyet Akademisi Okulları'nın mutlak otoritesi altında şekillenmiştir.

Kraliyet Akademisi'nin kuruluş amacı, akademisyenlerin ve büyük İngiliz portre sanatçılarının dünya literatüründeki yerlerini yükseltmek ve bu amaca hizmet edecek yeni sanatçılar yetiştirmektir. Akademi, özellikle monarşinin ayrıcalıklı dünyasını anlatan ulusal bir söylem geliştirmek için bir misyon edinmiştir. ${ }^{2}$ (Res. 1) Bir başka açıdan Kraliyet Akademisi, 19. yüzyılın başından itibaren genç sanatçıların kendilerini himaye edeceği, finansman sağlayacak patronlarını bulabilecekleri ve toplu olarak çıkarlarının korunmasını talep edebilecekleri bir platform olarak hizmet verse de bir süre sonra kraliyet ailesinin, halkın sanat konusunda takdir ve ilgisini kazanan "ortak" bir beğeni geliştirmesi için kurulmuş bir okula dönüşmüştür. (Res. 2)

Akademi, kurucu başkanı Sir Joshua Reynolds'ın, yaşadıkları yüzyılın siyasi ve sosyal gerçeklerinden giderek uzaklaşan ve sadece Rönesans Dönemi eserlerinin kopyasını çalışmak üzerine kurulu idealist eğitim sistemine karşı bir süre sonra öğrencileri arasından tepki görmeye başlamış ve genç sanatçılar tarafından çeşitli isim ve amaç birlikleri altında öğrenci grupları kurulmuştur. ${ }^{3}$ Kraliyet Akademisi'nin eğitim prensiplerine karşı ortaya çıkan öğrenci grupları ${ }^{4}$ arasında en popüler olanı ise bir döneme eserleri ile adını veren Pre-Raphaelite Kardeşliği' dir. (Pre-Raphaelite Brotherhood; 1848-1854)

Londra'daki Kraliyet Akademisi'nin sanat anlayışına tepki olarak bir araya gelen üç akademi öğrencisi William Holman Hunt, Dante Gabriel Rossetti ve John

1 Bk. Homans, 1998; Griffin, 2012.

2 Bk. Denis ve Colin, 2000, 120.

3 Bk. Gere, 1995, 8.

4 19. yüzyılın ilk yarısında Kraliyet Akademisi öğrencileri arasında kurulan sayısız edebiyat ve sanat topluluklarına ilişkin detaylı bilgi için Bk. Grieve, 1984, 23-5.

5 Bu çalışmada, Rafael Öncesi Kardeşliği ya da Ön Rafaello Kardeşliği olarak da tanımlanabilecek Pre-Raphaelite Brotherhood tanımı için; hem grubun özgün adına referans vermesi, hem de uluslararası literatür ile dil birliğinin sağlanması amacıyla Pre-Raphaelite Kardeşliği tanımı kullanılmıştır. 


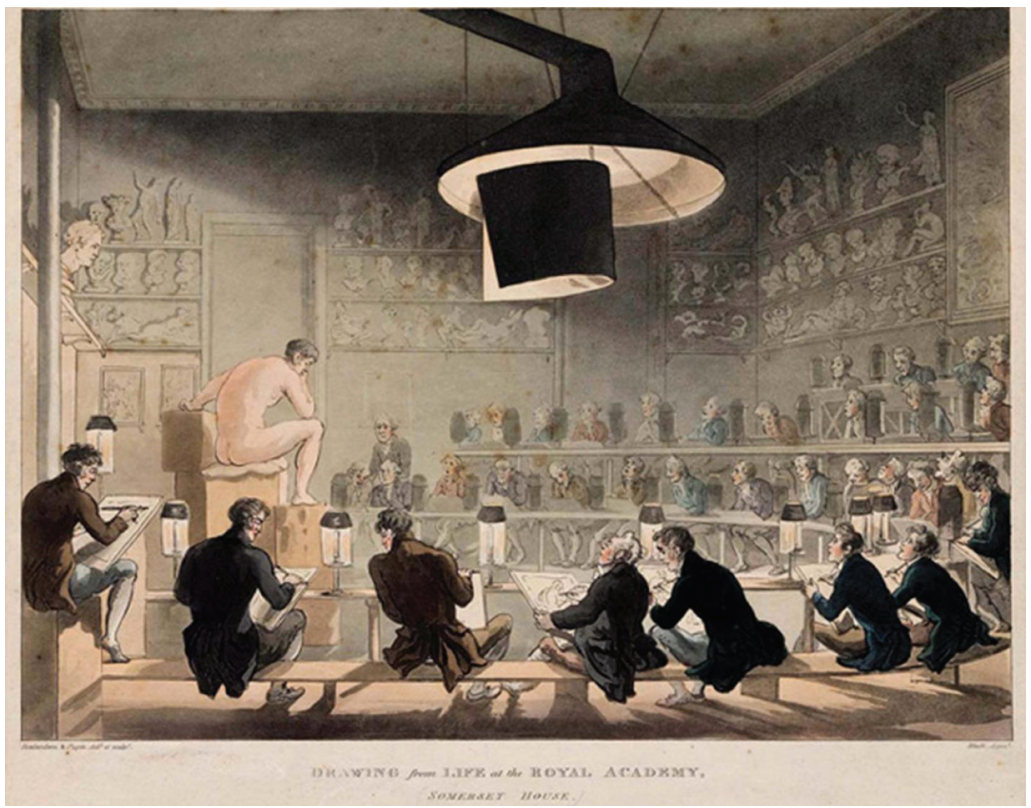

Resim 1: Kraliyet Akademisi'ndeki derslerden görünüm, 1808. Thomas Rowlandson ve Augustus Charles Pugin, Kağıt üzerine suluboya, 23.0 x $27.5 \mathrm{~cm}$ (kaynak:www.grabadosantiguos-coleccionfurio.com/obras0112.php) (Erişim: 17.02.2017)

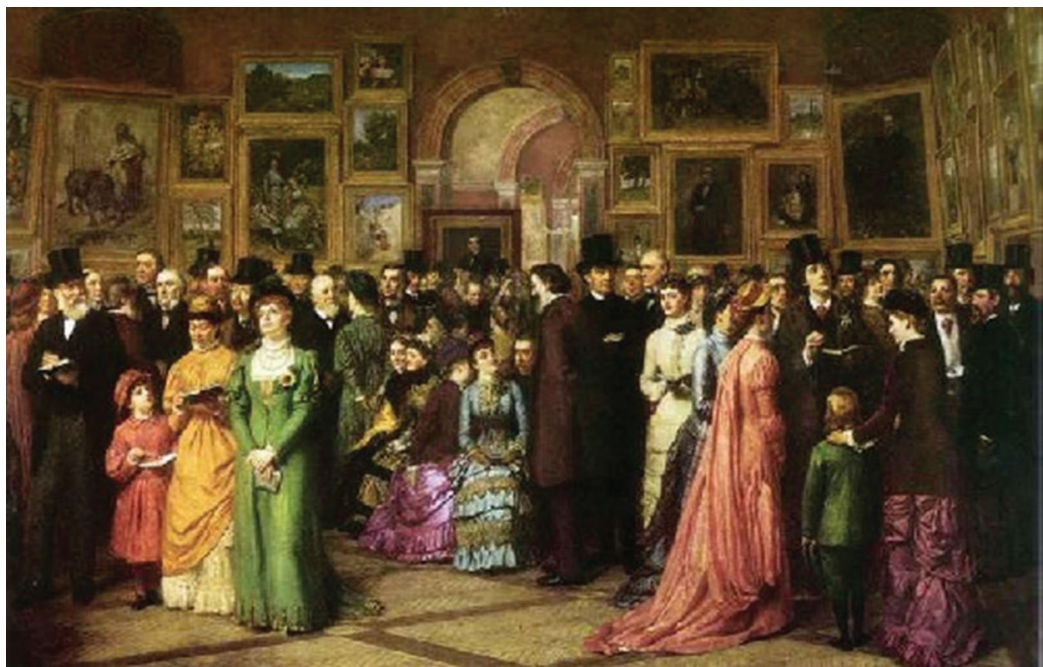

Resim 2: Kraliyet Akademisi’nin düzenlediği sergilerden görünüm 1800, 1881. William Powell Frith, tuval üzerine yağlıboya, 102.9 x 195.6 cm, Özel Koleksiyon. (Kaynak: Spalding, 1978, 27) 
Everett Millais, 1848 yılının Eylül ayında Pre-Raphaelite Brotherhood (Pre-Raphaelite Kardeşliği) adında bir grup kurmuşlardır. Grubun üç kurucu üyesine kısa bir süre sonra ressam Frederic George Stephens, heykeltıraş Thomas Woolner, ressam James Collinson ve eleştirmen William Michael Rossetti de katılmıştır. ${ }^{6}$ (Res. 3)

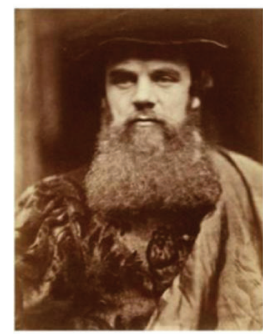

w. Holman HUNT

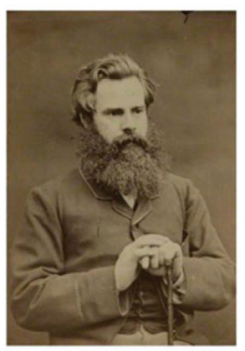

Thomas WOOLNER

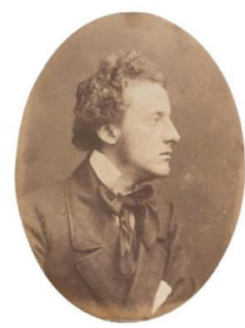

J. Everett MILLAIS

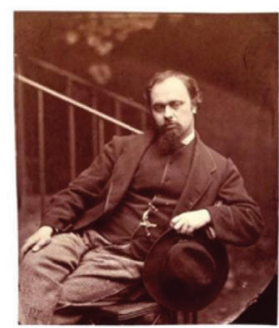

D. Gabriel ROSSETTI

Resim 3: Pre-Raphaelite Kardeşliği üyeleri. (Kaynaklar Kaynakça sonunda verilmiştir.)

Pre-Raphaelite Kardeşliği, sadece bir öğrenci topluluğu olmanın ötesinde, kendilerini Rönesans öncesi dönemin sanat anlayışına yakın bulan ve yaşadıkları çağa ilişkin gözlemlerini, Rönesans öncesi dönemin teknik ve stil birliği ile ifade etmeyi seçen bir hareketinin kuruculardır. Pre-Raphaelite Kardeşliği, akademik sanatın geleneksel kurallarına başkaldırı olarak sanatın bir tür ahlaki amaca hizmet etmesi gerektiğini savunmuştur. Grubun amacı; ciddi ve önemli konular hakkında resim yapmak, bu resimleri yaparken figür ve nesneleri doğrudan doğadan çalışmak ve seçilen konuyu en gerçekçi şekilde verebilmektir. ${ }^{7}$

6 Bk. Wood, 1997, 9-10.

7 Bk. Prettejohn, 2000, 37. 
Pre-Raphaelite Kardeşliği'ni çağdaşlarından farklı kılan ve bugün “bir sanat hareketi" olarak tanımlamamıza neden olan tek şey, akademi karşıtı gerçekçi tasvirleri değildir. Kardeşlik üyeleri, İngiltere'de gerçek dünyaya bakıp onu resmetmeye dayalı bir sanat anlayışını yaygınlaştırmak istemiş, Ruskin'in doğaya yönelen bakış idealini ${ }^{8}$ alarak seçtikleri konuları, fizyolojik ve "psikolojik" gerçekliğe uygun biçimde tasvir etmişlerdir. Böylece genç sanatçıların resimlerindeki her detay, sembolik bir anlam kazanmıştır.

Grubun çalışmalarını kendisine yakın bulan çok sayıda genç ressamı da etkileyen sanat anlayışları ile Pre-Raphaelite Kardeşliği, eserlerinde kullandıkları gerçekçi doğa ve figür tasvirlerini, bazen tarihî veya edebî hikâyeler aracılığı ile bazen de tanığı oldukları modern-yaşam konulu veya dinî temalı resimlerde göstermeye çalışmışlardır. Başka bir deyişle genç ressamlar, her sahnenin "gerçek" naturalistik manzara ya da iç yüzlerini göstermeyi, her figürü gerçek oranlar kullanarak ve herhangi bir sanatsal düzenlemeye referans vermeksizin doğrudan bir modele dayandırmayı tercih ederken beraberinde "gruba özel” bir sembolizm anlayışını da geliştirmişlerdir. Öyle ki Pre-Raphaelite Kardeşliği'nin eserlerinde kullandıkları ve 19. yüzyıl İngiliz resmine kendileri tarafindan kazandırılan bir yenilik ${ }^{9}$ olduğunu düşündükleri gerçekçi doğa tasvirleri, grubun kuruluşundan itibaren üyelerinin, eserleri için seçtikleri konuyu çeşitli semboller ile zenginleştirmesiyle farklı bir boyut kazanmıştır.

Pre-Raphaelite Kardeşliği'nin “yaşadıkları dünyanın neye benzediğini ya da nasıl göründügünü anlatmaya çalışırken eş zamanlı olarak aynı dünyanın ne anlama geldiğini ve onları nasıl etkilediğini" "10 ifade etmeyi de amaçlayan tasvir anlayışlarındaki sembolizm, aslında bir bakıma grubun kuruluş ideallerine de uygun düşmektedir.

Pre-Raphaelite Kardeşliği üyeleri, resimlerini açık havada ve doğrudan tabiat içinde en doğal hali ile duran modelden veya nesneden çalışırken, resmettikleri gerçekçi nesnelere simgesel anlamlar yüklemiştir. Hatta grubun resimleri, sergilendiği dönemde, sadece gerçekçi bakış açıları nedeniyle eleştirilmemiş, seçtikleri konuları ve bunları ele alış tarzları nedeniyle anlaşılamadıkları için de sorgulanmıştır. ${ }^{11}$

8 Avrupa resminin Rönesans sonrası geleneğini, stilize ve formüle edildiği için reddedip doğanın gerçeklerine yönelen ressam, yazar John Ruskin (1819-1900); Modern Painters (London, Smith, Elder and Co., 1848) kitabı ile başlattığı, devamını yazılı açıklamalar ile getirdiği ve sonrasında da ortak çalışmalarda bulunduğu Pre-Raphaelite Kardeşliği'nin sanat anlayışı üzerinde güçlü bir etkiye sahip olmuştur. Ruskin'in Pre-Raphaelite Kardeşliği'ne olan etkisine dair detaylı bilgi için Bk. Tobin, 2000; Hilton, 2010.

9 Pre-Raphaelite Kardeşliği' nin kurucu üyelerinden J. W. Hunt'ın konu hakkındaki yorumları için Bk. Hunt, 1905, 94-109.

10 Bk. Brooks, 1984, 134.

11 Pre-Raphaelite Kardeşliği'nin sergilerde yer alan resimlerine yönelik yapılan tüm eleştiriler için Bk. Tobin, 1996. 
J. E. Millais'in 1850 yllı Kraliyet Akademisi sergisinde yer alan ve ağır eleştirilere maruz kalan Ailesinin Evinde İsa (Christ in the House of His Parents) adl1 resmi, bu anlamda önemli bir örnektir. (Res. 4) Resim, sadece kompozisyon içindeki figürlerin, günlük hayatta herkesin karşısına çıkabilecek nitelikte çizgilere sahip olması nedeniyle gündemi işgal etmemiştir; eser, birçok açıdan toplum için kutsal olarak kabul edilen ve tartışılması olanaksız olan bazı değerlerin, yeniden ve yoruma açık sembollerle izleyiciye sunulması bakımından da dikkat çekicidir.

Resimde, İsa'nın elinden düşen bir damla kan, ayağı üzerindedir. Tıpkı, İsa'nın hemen arkasında duvar üzerinde görülen aletlerin, çekilen acıların enstrümanı haline gelmesi gibi, resimdeki her detay 'Çarmıh' sahnesini kurgulamaktadır. ${ }^{12}$ Arka planda duvar üzerindeki aletlerden gönye, üç köşesi ile Üçlü Birliği (Baba, Oğul ve Kutsal Ruh), hemen yanında cennete giden yolu anlatan merdiven üzerindeki güvercin ise Kutsal Ruhu sembolize etmektedir. ${ }^{13}$ Millais, kompozisyonun neredeyse tamamında günlük yaşamın kişi ve nesnelerini kutsal figürler üzerinde kullanarak yüksek derecede sembolik ve gerçekçi bir eser meydana getirmiştir.

Millais, Ailesinin Evinde İsa'da din sembolizmini Kutsal Aile ve bu aileyi gelecek günlerde bekleyecek olayları gündeme getiren semboller ile kurgularken radikal bir şekilde aileyi sıradanlaştırmıştır. İngiliz resim tarihinde o güne kadar yapılan tüm Meryem ve İsa tasvirleri saygındır. Bu ikili, görsel sanatlar içinde Hıristiyanlığı ve onun maneviyatını temsil eden en yüksek figürlerdir. Bu nedenle Meryem ve İsa'ya duyulan sonsuz saygı beraberinde dokunulmazlığ 1 getirmiştir. Ancak genç sanatçı, resminde saygınlığın ifadesi olan eski formları ve ikonografiyi kısmen devam ettirirken, Meryem'in yeni görüntüsü ile izleyiciyi şaşırtarak yeni bir süreci başlatmış olmalıdır.

Başta yazar Charles Dickens ${ }^{14}$ olmak üzere, akademi ve sanat çevrelerince Millais'nin resminde herkesin eleştirdiği şey, yaratılan figürlerin neredeyse fakir bir mahalleden çıkmış gibi gözükmeleridir. ${ }^{15}$ Resimdeki aile, Kutsal aileyi temsil etmesine rağmen, soyluluk, güzellik ve kutsallık gibi kavramlardan uzaktır. Eleştirilerin bu denli

12 Bk. Prettejohn, 2000, 243.

13 Bk. Landow, 1980, 124.

14 Yazar Charles Dickens'ın Millais'nin resmi ile ilgili yaptığı eleştiriyi okumak için Bk, Dickens, $1850,12-13$.

15 Millais'nin, özellikle 19. yüzyıl İngiliz resim sanatı için yeni sayılabilecek Kutsal Aile tasvirindeki figürlerin sıradan görünümü, aslında Avrupa Resim sanatı tarihi içinde karşımıza çıkan ilk deneme değildir. Bu bağlamda, Barok resim sanatının önemli isimlerinden Caravaggio'nun 17. yüzyılın başında tamamladığı Madonna dei Palafrenieri adlı resmi kayda değerdir. Kompozisyon içinde Meryem, oğlu İsa ile insanlığı 'günah' ile tanıştıran yılanı ezmektedir. Ressam, başları üzerine kutsiyetlerini belirten haleleri yerleştirmesine rağmen Meryem ve çocuk İsa’yı, doğal görünümleri ile resmetmiştir. Meryem, burada çocuğu için endişelenen bir anne, İsa ise çevresini yeni keşfetmeye başlayan gerçek bir çocuktur. Resim için Bk. http://www.galleriaborghese.it/it/ madonna-dei-palafrenieri. 


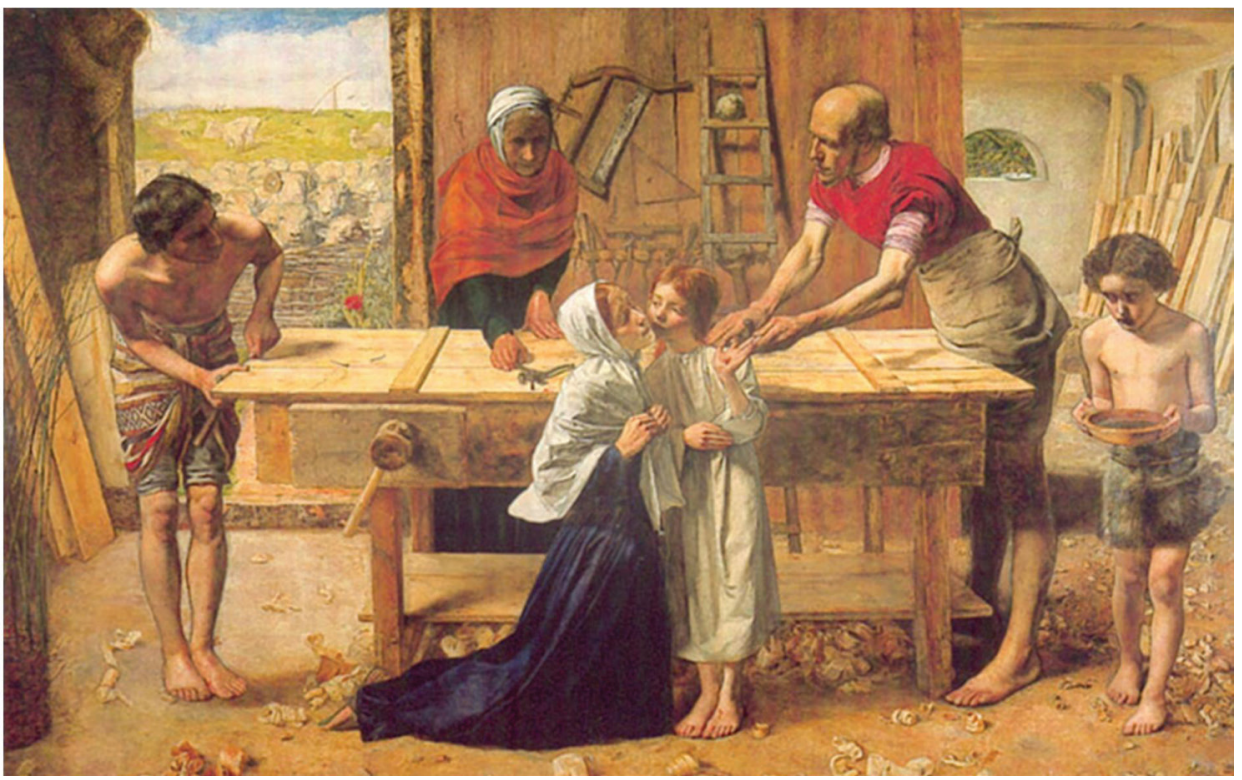

Resim 4: Ailesinin Evinde İsa / Christ in the House of His Parents, 1849-1850.

J. E. Millais, tuval üzerine yağlıboya, 86.4 x $139.7 \mathrm{~cm}$, Tate Gallery.

[http://www.tate.org.uk/art/artworks/millais-christ-in-the-house-of-his-parents-the-carpenters-shop-n03584] (Erişim: 17.02.2017)

ağır olmasının nedeni, Endüstri Devrimi sonrası sınıflar arasında meydana gelen ekonomik uçuruma bağlı fakir ve düşkün karakterlerin burada Kutsal Aile olarak izleyici karșısına çıkmasıdır. Bir başka açıdan Viktorya İngiltere'sinde yaşanan toplumsal yaşamdaki bölünmüşlük ${ }^{16}$ Millais'nin resminde açık bir biçimde kendisini göstermiş̧ir.

Pre-Raphaelite Kardeşliği'nin sembolik resimlerinde tutucu ve obsesif bir şekilde nesneleri gerçekçi ve aslına uygun verme isteği, aslında onların eserlerindeki manevi anlamın kaybolmamasına yönelik geliştirdikleri bir savunma aracıdır. Sanatçılar, resmettikleri nesneleri herhangi bir şekilde idealize ettiklerinde veya formunu değiştirdiklerinde, resmin izleyici üzerindeki manevi etkisini yitireceğine ve odak noktasının resmin anlamından nesneye veya manzaraya yöneleceğine inanmışlardır. $\mathrm{Bu}$ nedenle gerçekçi tasvirler, Pre-Raphaelite sembolizmi içinde güçlü ve önemli bir araç haline gelmiştir.

16 İngiltere için 19. yüzy1l, oldukça önemli ve dramatik değişimlerin yaşandığı bir dönem olmuştur. Endüstri Devrimi'nin etkisini arttırdığg 19. yüzyılın ilk yarısından itibaren, toplumun en temel ve küçük unsurlarından (aile gibi), üzerinde en çok uzlaşılan öğelerine kadar (din gibi) etkisi yıllarca sürecek olan değişimler yaşanmıştır. İngiltere'de 18 ve 19. yüzyıl boyunca etkisi güçlü bir şekilde yaşanan Endüstri Devrimi'nin toplumsal hayat üzerindeki etkilerine ilişkin detaylı bilgi için Bk. Stevenson, 1993, 229-253. 
Grubun diğer üyesi Rossetti, İște Rabbin Hizmetçisi! (Ecce Ancilla Domini!)'nde kardeşliğin figüratif amaçlarına hizmet ederken, Viktorya Dönemi resim sanatı içinde, geleneksel müjde ikonografisine yarattığı gerçekçi sahne ile yine farklı bir yaklaşım getirmiştir. (Res. 5) Rossetti, Meryem'i tasarlarken, erken dönemin sert ve ifadesiz Meryem tasvirleri yerine burada çok daha gerçek genç bir kadın yaratmaya çalışmıştır.

Ressam, bilinçli olarak tuvalindeki renkleri beyaz ve üç ana renk ile sınırlamıştır. Cennetin simgesi mavi, Meryem ile ilgilidir. Kırmızı ise İsa'nın kanını simgelemektedir. ${ }^{17}$ Sarı renk, kutsal haleler için kullanilırken, Rossetti benzer bir sembolizmi kurgulamak için muhtemelen Meryem'i de kızıl saçlı vermiştir. Rossetti, resmi ile Pre-Raphaelite sembolizmi içinde gerçekçilik kavramının ne olduğuna dair Millais'nin Ailesinin Evinde İsa's1 ile eş zamanlı olarak ilk fikirlerin de ortaya çımasına neden olmuştur. Kompozisyon, bütünüyle tuval üzerindeki her rengin gerçek dünyada, bir duyguyu ya da düşünceyi temsil etmesi ilkesine dayanmıştır. Hikâyenin özüne ve ana fikrine bağlı olarak şekillenen renkler, parlak kullanımı ile izleyicinin dikkatini çekerken kompozisyonun içeriği ve manevi dünyasına dair referans vermiştir.

Sanatçı, resimde meleğin Meryem'e uzattığı, saflığın ve masumiyetin sembolü zambak gibi, kullandığ birçok detayı geleneksel kurallara dayandırarak kurgulamıştır. Başka bir deyişle kardeşlik, bu resimleri ile Rönesans öncesi veya sonrası dönemlerin sanatlarından seçtiği sembolleri de kullanmaya devam etmiştir. Burada eseri farklı kılan unsur ise resimdeki sembollerin kullanış biçimi ve yarattı̆̆ kompozisyonun sıradan görüntüsüdür. Bu stil, tamamen Rossetti ile birlikte Pre-Raphaelite Kardeşliği üyelerinin icadı olan yeni bir anlayışın ürünüdür.

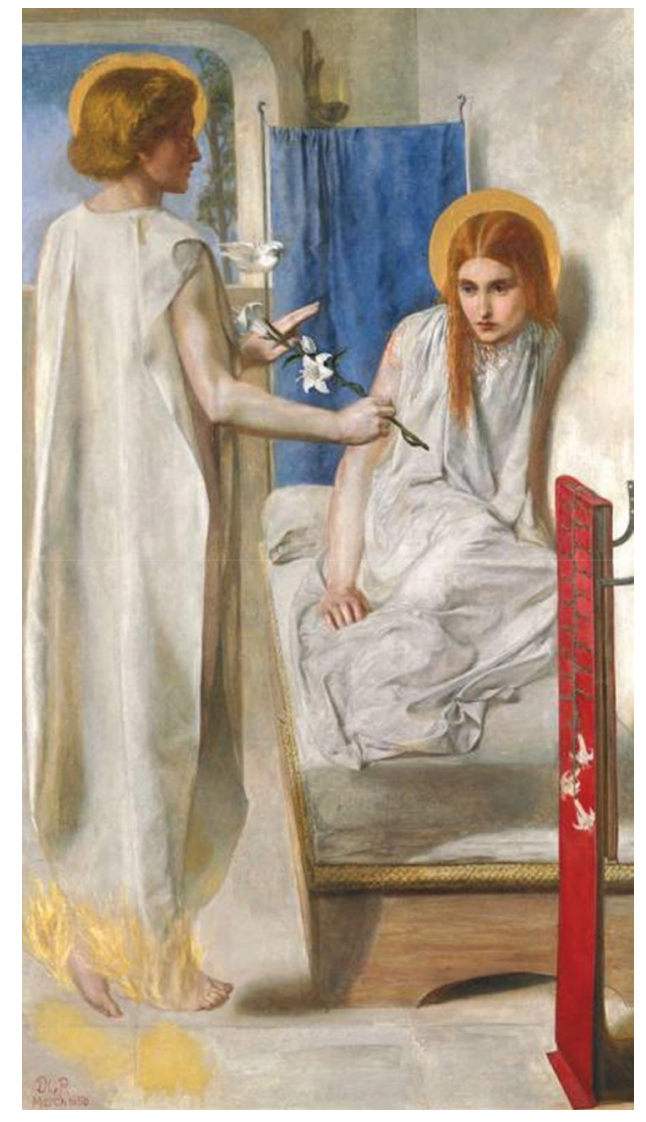

Resim 5:

İşte Rabbin Hizmetçisi! / Ecce Ancilla Domini!, 1849-1850.

D. G. Rossetti, tuval üzerine yağlı boya, $72.4 \mathrm{x}$ $41.9 \mathrm{~cm}$, Tate Gallery.

[http://www.tate.org.uk/art/artworks/rossetti-ecce (Erișim: 17.02.2017) ]

17 Bk. Cheney, 1992, 256. 
Rossetti'nin 1849 yılında ilk resmi ile ipuçlarını verdiği, 1854 yılında Hunt'ın Kudüs'e gitmeden önce sergilediği çalışmaları ile yetkin hale getirdiği Pre-Raphaelite sembolizmi; hem grubun, hem de sanatçıların kendi gelişimleri açısından İngiliz resim sanatı adına yeni bir dönemdir.

Pre-Raphaelite Kardeşliği’nin, dönemin dini, sosyal veya politik sorunları ile bağlantısı olacak şekilde kompozisyon içine yerleştirdiği semboller, grubun çalışmalarını gerçekçi bakış açısı ile birlikte İngiliz resmi içinde fark edilebilir kılan en önemli özellik haline gelmiştir. Dini konuların yanı sıra özellikle edebi metinler, PreRaphaelite sembolizmi içinde manevi öğretileri ve sosyal kaygıları tarif edebilmek için kullanılan araçların başında gelmektedir. Pre-Raphaelite Kardeşliği tarafından geçmiş ile modernin bir arada değerlendirilebileceği uygun kaynaklardan biri olarak belirlenen İngiliz edebiyatı, grubun eserlerindeki sembolizmin güncel yaşamın sorunlarına referans verecek şekilde kurgulanmasına olanak tanımıştır.

Hunt'ın, Shakespeare'in sevgi, sadakat, arkadaşlık, ihanet ve bağlılık temalarını konu alan "Veronalı İki Centilmen" adlı eserini yorumlayan Valentine'nin Sylvia'y1 Proteus'tan Kurtarışı (Valentine Rescuing Sylvia from Proteus)'1 (Res. 6), Pre-Raphaelite sembolizminin edebî metinler aracılığıyla da İngiliz resmine getirdiği yeniliğin ne olduğunu açıkça göstermesi bakımından önemlidir.

Resimde, Valentine, hain ve vefasız arkadaşı Proteus'u, Sylvia'ya tecavüz etmeye kalkıştığı için kınamaktadır. İki erkek arasındaki gerilimi, Valentine'ın tepeden bakan ve aşağılayan bakışları anlatmaktadır. Bu sahnede Proteus, utanç içinde yere diz çökmüş hali ile 'düşmüş erkek' olarak tanımlanabilir. Hunt, bir anlamda 19. yüzyıl sanatında sıkça karşılaşılan "düşmüş kadın” teması ile ilişkilendirilebilecek bir tasviri, burada farklı bir versiyonu ile resmine adapte etmiş görünmektedir.

Hunt'ın 19. yüzyıl Viktorya Britanyası'nın bakış açısı ile ele aldığı tema, Sylvia tasvirinde kendisini göstermiştir. 19. yüzyılda Viktorya toplumunda ihanet eden kadın için beklenen son, bellidir: Toplumdan dişlanmak. Kompozisyonun sol tarafında ayakta duran Julia, Proteus'un canlı yeşil alan üzerindeki varlığına karşın, kuru yapraklar arasındadır. Bu da Viktoryen kadının kaderini sembolize etmektedir.

Pre-Raphaelite Kardeşliği, özellikle Shakespeare'in kadın karakterlerini, Viktoryen toplumun, kadının ahlaki faziletlerine dair geliştirdiği olguları ile yeniden yaratmaya çalışmışlardır. Ahlak gibi dini çatışmalar da Pre-Raphaelite ressamlarının Shakespeare'in oyunlarında bulduğu temalardan olmuştur. Edebiyat dünyasından seçilen eserlerden hareketle resmedilen karakterler, manevi öğretileri ifade etmek ve sosyal kaygıları tarif edebilmek için Pre-Raphaelite sembolizmi içinde araç haline gelmiştir. Pre-Raphaelite Kardeşliği tarafından geçmiş ile modernin bir arada değerlendirilebileceği bir yöntem olarak belirlenen İngiliz edebiyatı, grubun eserlerindeki sembolizmin güncel hayat ile ilişkisini kurmasına yardımcı olan özelliklerden biri olarak değerlendirilebilir. 


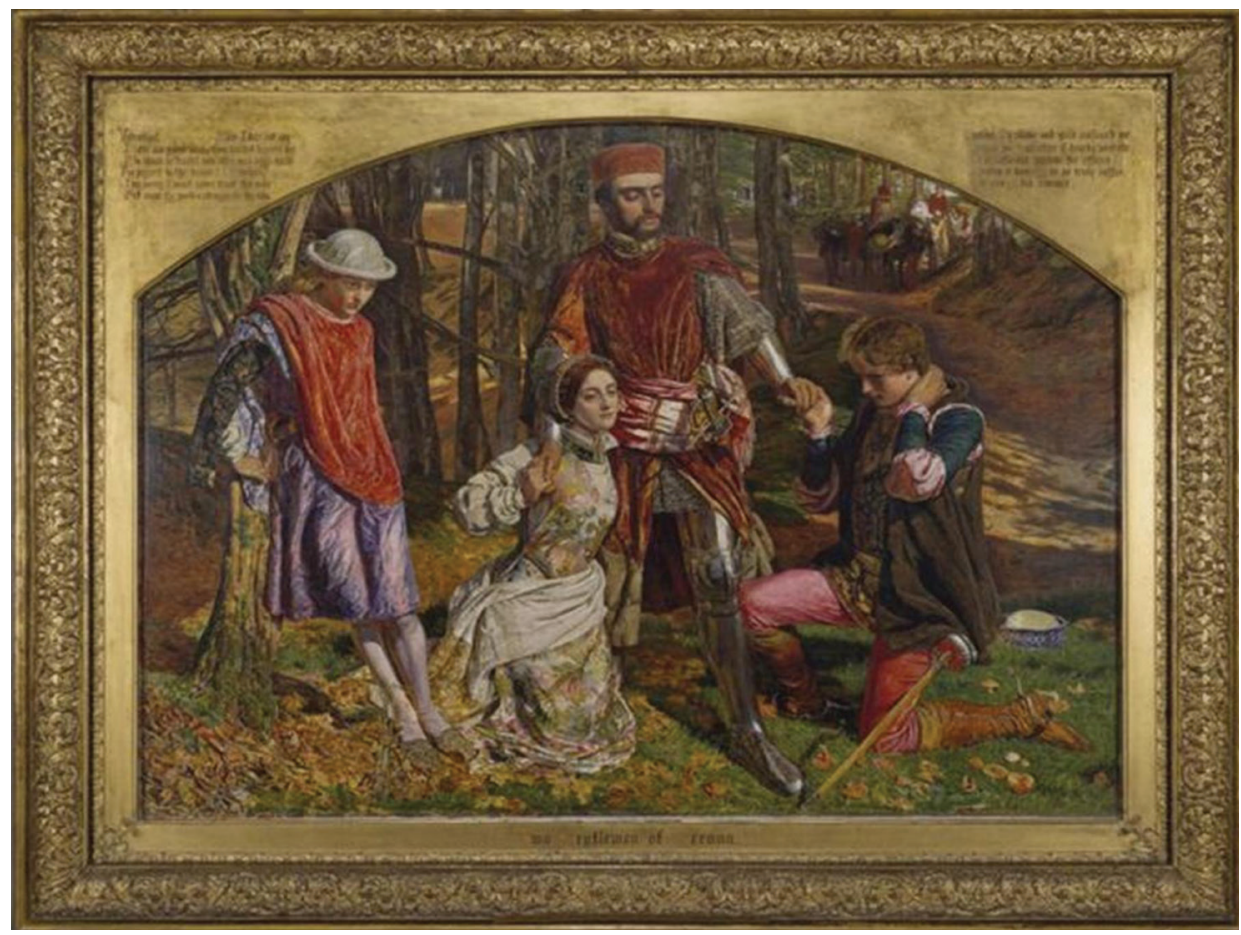

Resim 6: Valentine'nin Sylvia'yı Proteus'tan Kurtarış1 / Valentine Rescuing Sylvia from Proteus, $1850-1851$

W. H. Hunt, tuval üzerine yağlıboya, 98.5 x $133.3 \mathrm{~cm}$, Birmingham Museums and Art Gallery.

[ http://www.bmagic.org.uk/objects/1887P953 (Erişim: 17.02.2017) ]

Pre-Raphaelite Kardeşliği, dinî, edebî ya da sosyal-politik sembolizmi resimlerinde kullanırken izleyiciye önerdiği çözümü desteklemek için ise açıklayıcı şiirler veya metinler kullanmıştır. Bu yazılar, genellikle sergi kataloğunda veya resmin çerçevesi üzerine işlenerek yayınlanmıştır. Örneğin Hunt, Valentine'nin Sylvia'yı Proteus'tan Kurtarışı'nda; çerçevenin soluna Valentine'ın, sağına ise Proteus'un oyundaki diyalogları yerleştirmiştir. Böylece resmin manevi içeriğine dair hiçbir detayın kaybolmaması, ressamı tarafından garanti altına alınmıştır.

Kardeşlik, resimlerinde toplumun Endüstri Devrimi sonrası yaşadığı sosyal sorunları anlatırken çözüm de sunan resimler yapmıştır. Yeni İngiliz toplumunun geldiği noktadan rahatsız olan grup, sanatları ile çevrelerini eleştiren bir anlayışı geliştirmeye çalışmışlardır. Aslında Pre-Raphaelite Kardeşliği'nin günlük hayatı konu alan sahneleri, özellikle Viktorya Dönemi resimlerinde karşılaşılan bir konu olmasına rağmen grubun resimleri, kullandıkları semboller ve yalın kompozisyonları nedeniyle ön plana çıkmıştır. 
Pre-Raphaelite Kardeşliği’nin resimlerinde sembolizm, figürden manzaraya kadar çeşitli kişi ve nesnelerin birlikteliği ile kurgulanmıştır. Resimlerde görülen hiçbir öğe, çalışmanın konusundan ve vermek istediği mesaja bağlı simgesel anlatım dilinden bağımsız değildir. Kardeşlik; ister dinî, ister edebî temalı olsun, Viktoryen toplumun gün geçtikçe derinleşen farklılıklarını vurgulayan bir anlayışı resimlerinde kullanmıştır. Denilebilir ki kardeşlik üyelerinin İngiliz resmine getirdiği yenilik, resminde kullandığı sembollerden çok, sembolizmin içindeki temalar ile ilgilidir. Genç sanatçılar, resimlerinde çağdaş ve modern olarak adlandırdıkları Viktoryen toplumun yaşadığı değişimi anlatmış ve gerçekçi eserler yaratmıştır.

Sonuç olarak Pre-Raphaelite sembolizmi; dönemin din, edebiyat, sosyal ve politik yaşamındaki değişikliklere bağlı konu seçimleri ve uygulamada karşılaşılan çeşitli metotların varlığına bağlı olarak değişim göstermektedir. Bu nedenle grubun eserlerindeki konular ile bu konuların semboller aracılığı ile izleyiciye aktarılması sırasında uygulanan yöntemler, Pre-Raphaelite sembolizminin ilkelerini belirlemiştir. Pre-Raphaelite Kardeşliği içinde Millais'nin Ailesinin Evinde İsa'sı ile başlayan ve Hunt'in Dünyanın Işığı (The Light of the World) (Res. 7) adlı yapıtı ile açık bir mesaja dönüşen din sembolizmi, grubun Sanayi Devrimi'nin etkisi ile yok olan etik değerlerini halka yeniden hatırlatmak için geliştirdiği yöntemlerden biridir. Hunt'ın hayat kadınlarını konu alan Vicdanın Uyanışı (The Awakening Conscience) (Res. 8), din adamlarının içinde bulundukları tartışmalar nedeniyle unuttuğu halkı hatırlatan Kiralık Çoban (The Hireling Shepherd) (Res. 9), Millais'nin Viktoryen toplumda ahlaklı kadını temsil eden Mariana (Res. 10) ve siniflar aras1 çatışmaları gündeme getiren Ormancının K1z1 (The Woodman's Daughter) (Res. 11)

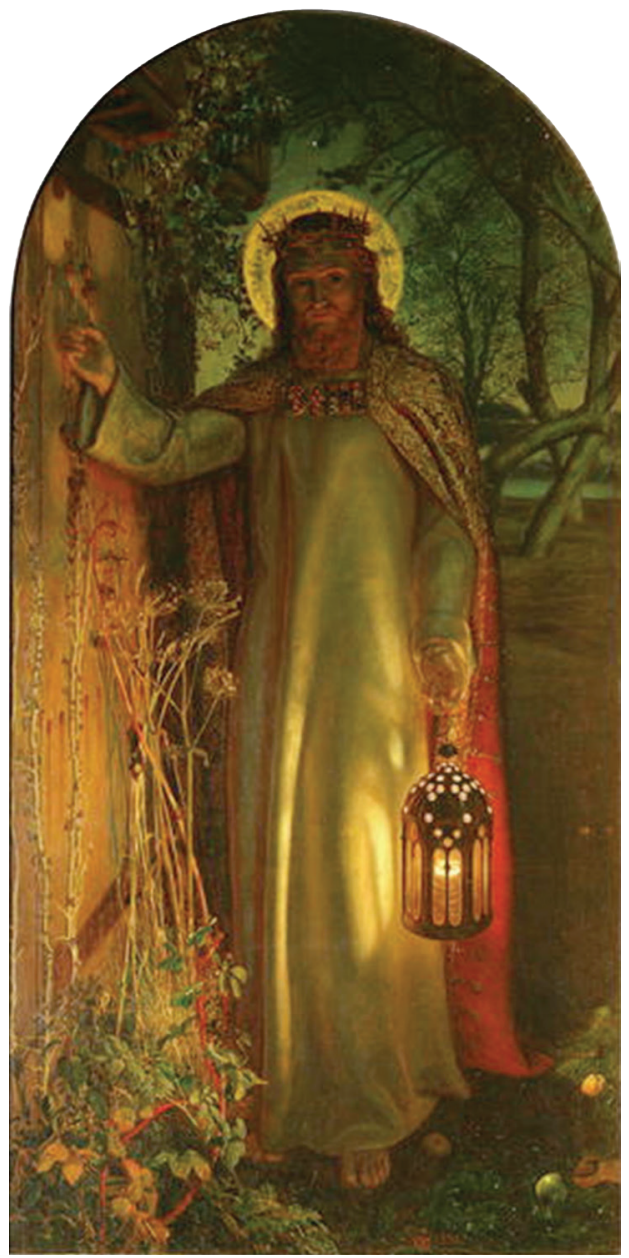

Resim 7:

Dünyanın Işığı / The Light of the World, 18511853.

W.H. Hunt, tuval üzerine yağlıboya, 49.8 x 26.1 cm, Manchester Art Gallery.

[http://manchesterartgallery.org/collections/search/ collection/?id=1912.53) (Erişim: 17.02.2017) ] 


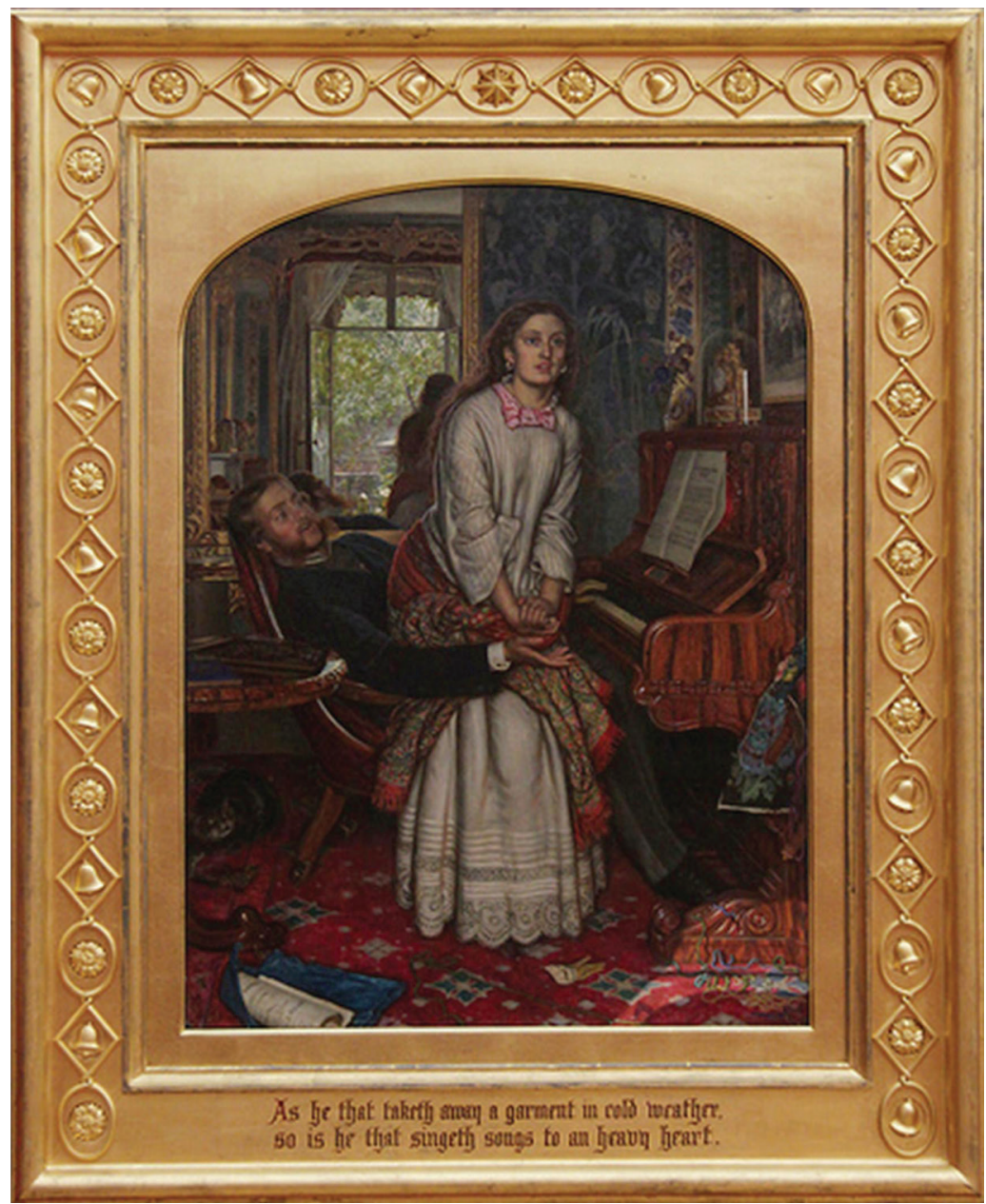

Resim 8: Vicdanın Uyanış1 / The Awakening Conscience, 1853-1854.

W. H. Hunt, tuval üzerine yağlıboya, 76.2 x $55.9 \mathrm{~cm}$, Tate Gallery.

[ http://www.tate.org.uk/art/artworks/hunt-the-awakening-conscience-t02075 (Erişim: 17.02.2017) ]

ile yarattığ 1 sosyal ve politik sembolizm, izleyicilerin günlük hayatta karşılaştıkları etik çatışmaları görmeleri için, 'zorlayan' yöntemlerin somutlaştığı örneklerdendir.

Pre-Raphaelite Kardeşliği’nin 19. yüzyılda İngiliz resmine getirdiği dinamizm, grubun adı ya da aydınlık kompozisyonları ile yarattığı etki ile birlikte dinî, sosyal, siyasi ve edebî konuların, izleyicinin günlük hayatında yaşadığg sorunlar, olaylar ve gelişmelere referans verecek şekilde sanatta karşılığını bulmasıdır. Sıradan hayatın günlük olaylarla 


\section{Resim 9:}

Kiralık Çoban / The

Hireling Shepherd, 1851-1852.

W. H. Hunt, tuval üzerine yağliboya, 76.4 x $109.5 \mathrm{~cm}$, Manchester Art Gallery.

[ http://manchesterartgallery. org/collections/search/ collection/?id=1896.29 (Erișim: 17.02.2017) ]

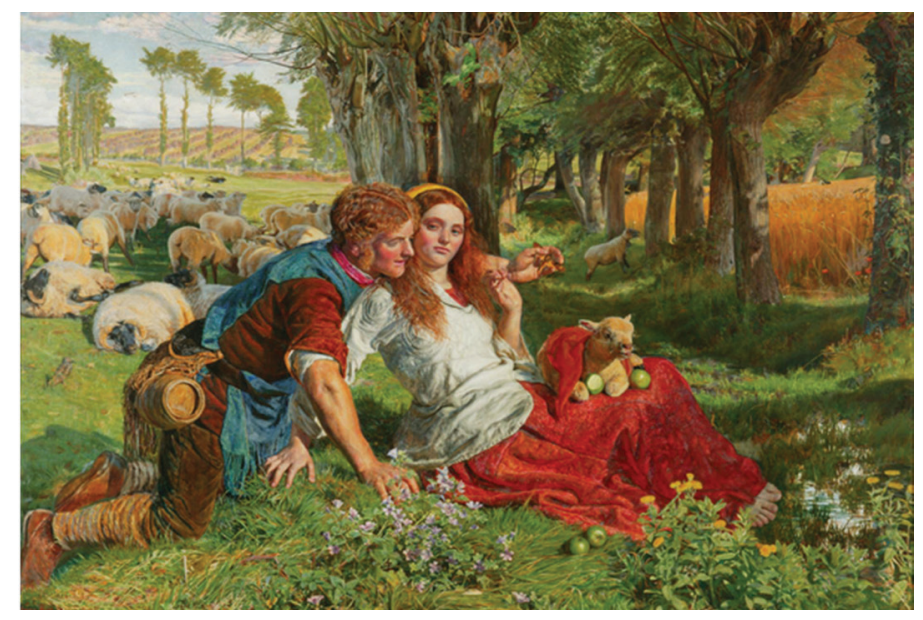

Resim 10: Mariana, 1850-1851.

W. H. Hunt, tuval üzerine yağlıboya, 59.7 x $49.5 \mathrm{~cm}$, Tate Gallery.

[ http://www.tate.org. uk/art/artworks/millaismariana-t07553 (Erişim: 17.02.2017) ]

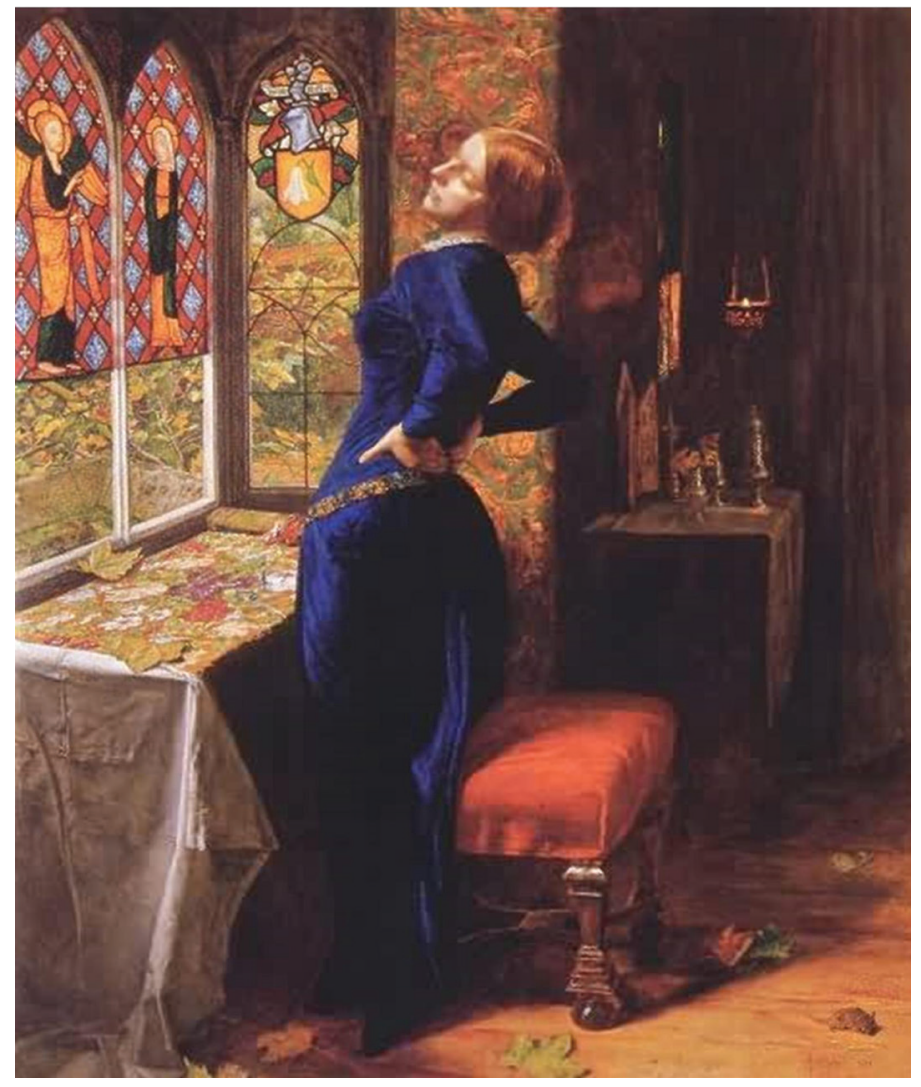




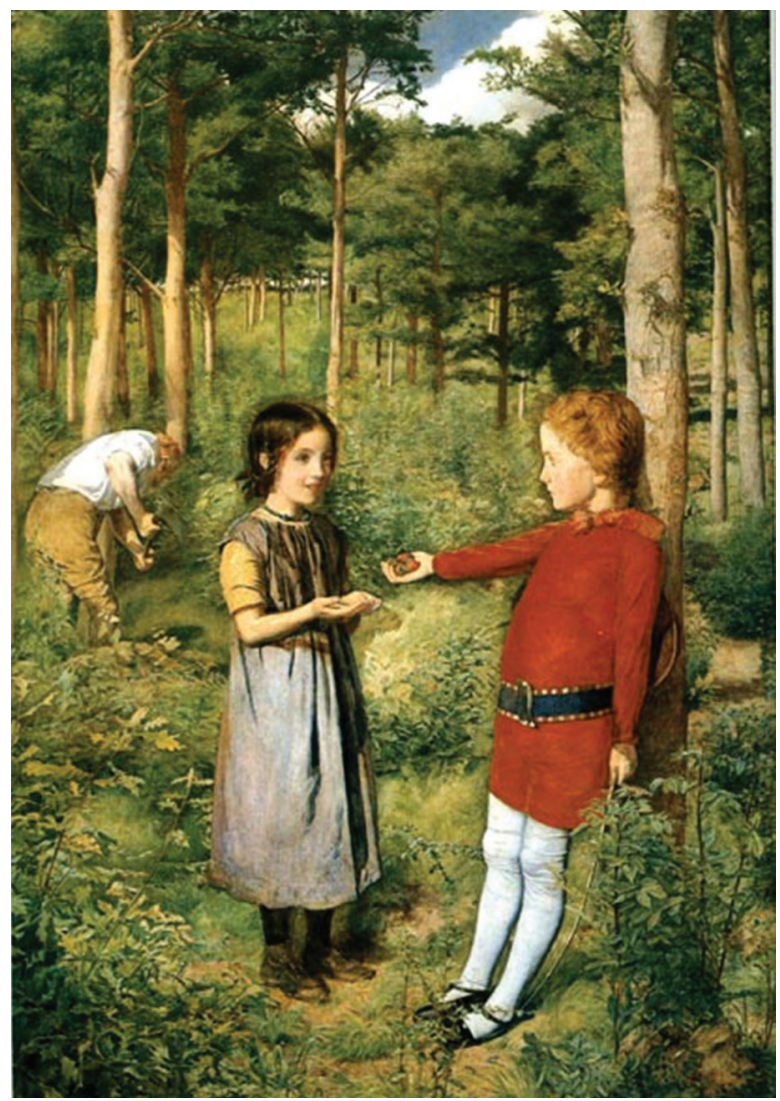

\section{Resim 11:}

Ormancinın Kizı / The Woodman's Daughter, 1850-1851.

J. E. Millais, tuval üzerine yağlıboya, $88.9 \times 64.8 \mathrm{~cm}$, Guildhall Art Gallery, Corporation of London.

[ http://www.victorianweb.org/painting/ millais/paintings/5.html (Erişim: 17.02.2017) ]

örülü kompozisyon öğeleri, Pre-Raphaelite sembolizmin en önemli dayanağı olmuştur. Böylece günlük hayatın akışı içinde görünmeyenin görünürlüğü arttırılmıştır.

Pre-Raphaelite Kardeşliği, eserlerine dini sanat içindeki ikonografiyi adapte ederek ahlaki açıdan ciddiyeti gündeme getiren resimler yapmış ve modern yaşamdaki provokatif konularla yüzleşerek eserlerine belli bir vizyon kazandırmaya çalışmıştır. Kardeşliğin bu amacına ulaşmasına yardımcı olan en önemli araçları ise sembolizm olmuştur. Kardeşlik, resimlerindeki sembolizm ile önceki nesillerin varsayımları ve inançlarını yeniden gözden geçirerek eleştiriyor gibi görünse de aslında en büyük ideali, alışılan düzene geri dönmektir. İster edebî, ister modern yaşamdan alınmış konular olsun, Pre-Raphaelite Kardeşliği toplumu, din aracılığ 1 ile iyileştirmeye odaklı bir sembolizmi eserlerinde kullanmışlardır. 


\section{KAYNAKÇA}

Brooks, C. (1984), Signs for the Times. Symbolic Realism in the Mid-Victorian World, London: George Allen \& Unwin.

Cheney, L. G. (Ed.) (1992), Pre-Raphaelitisim and Medievalism in the Arts, Wales: Edwin Melles Press.

Denis, R.C. ve Colin, T. (2000), Art and the Academy in the Nineteenth Century, New Jersey: Rutgers University Press.

Dickens, C. (15 Haziran 1850), Old Lamps for New Ones, Household Words (12), 12-14.

Gere, J. A. (1995), Pre-Raphaelite Drawings in the British Museum, London: British Museum Publications.

Grieve, A. (1984), Style and content in Pre-Raphaelite Drawings 1848-50, The PreRaphaelite Papers, ed. Leslie Parris, London: Tate Gallery Publishing, 23-43.

Homans, M. (1998), Royal Representations: Queen Victoria and British Culture, 18371876, Chicago: The University of Chicago Press.

Griffin, B. (2012), The Politics of Gender in Victorian Britain: Masculinity, Political Culture and the Struggle for Women's Rights, Cambridge: Cambridge University Press.

Hilton, T. (2010), The Pre-Raphaelites, London: Thames \& Hudson.

Hunt, W. H. (1905), Pre-Raphaelitism and the Pre-Raphaelite Brotherhood I, New York: E. P. Dutton\&Company.

Landow, G. P. (1980), Victorian Types, Victorian Shadows: Biblical Typology in Victorian Literature, Art, and Thought, London: Routledge \& Kegan Paul.

Prettejohn, E. (2000), The Art of the Pre-Raphaelites, London: Tate Publishing.

Ruskin, J. (1848), Modern Painters I, London: Smith, Elder and Co.

Spalding, F. (1978), Magnificent Dreams, Burne-Jones and the Late Victorians, New York: E.P. Dutton.

Stevenson, J. (1993), Social Aspects of the Industrial Revolution, The Industrial Revolution and British Society, ed. Patrick O'Brien ve Roland Quinault, Cambridge: Cambridge University Press, 229-253.

Tobin, T. J. (1996), The Critical Reception of Pre-Raphaelite Painting and Poetry: 18501900, Manchester: Heckman.

Tobin, T. J. (2000), John Ruskin's Defence of Pre-Raphaelitism in the London Times, The Pre-Raphaelite Society, Volume VIII, Number 1, 19-29.

Wood, C. (1997), The Pre-Raphaelites, London: Seven Dials.

\section{Pre-Raphaelite Kardesliği üyelerinin portreleri icin internet kaynakları:}

Hunt için http://www.npg.org.uk/collections/ (17.02.2017) Millais için http://www.npg.org.uk/collections/ (17.02.2017) D. Rossetti için http://www.npg.org.uk/collections (17.02.2017) Woolner için http://www. npg.org.uk/collections/search/portrait/ (17.02.2017) Collinson için https://www.mutualart.com/Artwork/ (17.02.2017) Stephens için http://www.npg.org.uk/collections/search/portrait (17.02.2017) W. M. Rossetti için http://www.npg.org.uk/collections/search/portrait (17.02.2017) 